THE POLITICAL ECONOMY OF

JAPAN'S LOW FERTILITY 


\section{The Political Economy of Japan's Low Fertility}

Edited by FRANCES MCCALL ROSENBLUTH

STANFORD UNIVERSITY PRESS STANFORD, CALIFORNIA 2007 
Stanford University Press

Stanford, California

(C) 2007 by the Board of Trustees of the Leland Stanford Junior University. All rights reserved.

No part of this book may be reproduced or transmitted in any form or by any means, electronic or mechanical, including photocopying and recording, or in any information storage or retrieval system without the prior written permission of Stanford University Press.

\section{Library of Congress Cataloging-in-Publication Data}

The political economy of Japan's low fertility / edited by Frances McCall Rosenbluth.

p. $\mathrm{cm}$.

Includes bibliographical references and index. ISBN-13: 978-0-8047-5486-6 (cloth : alk. paper)

1. Fertility, Human-Japan. 2. Women-Japan-Social conditions.

3. Women-Japan-Economic conditions. I. Rosenbluth, Frances McCall. HB1061.P65 2007

331.4

2006007573

Typeset by Newgen in 10/12.5 Palatino 